\title{
Curculio aneb Darmojed
}

\author{
Titus Maccius Plautus \\ Překlad Tomáš Weissar, Eliška Poláčková, Daniela Urbanová a Radek Černoch
}

Překlad ${ }^{1}$ dva tisíce let staré komedie Curculio římského komediografa Tita Maccia Plauta (asi 254-184 př. Kr.) vznikl jednak se záměrem zpřístupnit českému čtenáři, potažmo divákovi, text do češtiny dosud nepřeložené římské komedie, jednak také s úmyslem vyzkoušet, zda je Plauta opravdu tak těžké překládat, jak naznačoval zběžný pohled. Na začátku překladového semináře, který probíhal na Ústavu klasických studií Filozofické fakulty Masarykovy univerzity v r. 2015, stál dlouholetý odborný zájem Daniely Urbanové ze zmíněného ústavu o archaickou a speciálně plautovskou latinu a výzkum Elišky Poláčkové z Katedry divadelních studií v oblasti překladu Plautových komedií do češtiny. Jeho výsledkem bylo zjištění, že naprostá většina dosavadních českých překladů nezohledňuje všechny zásadní aspekty Plautova komického jazyka a autorského stylu, především pak jeho performativní aspekt - skutečnost, že se jedná o texty určené primárně k divadelnímu předvádění, nikoli k tichému čtení.

Výsledkem takovýchto literárně pojatých překladů, zejména z edice Antická knihovna nakladatelství Svoboda, jsou pak nezřídka texty, které paradoxně nejsou pro čtenáře zcela srozumitelné, protože zastírají situační rozměr replik, které odkazují k určitému dění na scéně a jsou pochopitelné jen tehdy, pokud si k nim čtenář představí odpovídající hereckou akci. Dalším výrazným zásahem do přediva originálního textu Plautových her pak od počátku plautovského překladu v r. 1821 až po zatím poslední (s výjimkou předkládaného) překlad Plautovy komedie Aulularia (Komedie o hrnci) z r. 1987 bylo vypouštění homoerotických aspektů palliaty, jak zní žánrové zařazení tohoto typu her. Oba tyto rozměry originálu se přítomný překlad snaží zachytit v míře co nejbližší původnímu dílu. Stejně tak se překladatelský tým snažil zprostředkovat všechny další podstatné charakteristiky Plautova dramatického stylu: širokou škálu jazykových variet sahající od nápodoby jazyka ulice přes profesní slangy (právnický, námořnický či obchodní jazyk) až po parodii tragického stylu, jazykové hříčky fonetického a morfologického rázu (zvukomalba, neologismy apod.), rozvinutou obrazivost a figurativnost odkazující k antickým rétorickým postupům - to vše smícháno v kypícím kotlíku karnevalové opulentnosti a nevázanosti.

1 Text vznikl v rámci projektu MUNI/FR/1394/2016 „Rímská komedie: inscenační workshop“ pro potřeby stejnojmenného výukového kurzu za finanční podpory z Fondu rozvoje Masarykovy univerzity. Jeho studentská inscenace byla kromě výše uvedeného projektu finančně podpořena Grantem DILIA 2018 a stipendiem rektora Masarykovy univerzity. Text překladu smí být reprodukován či inscenován pouze se souhlasem autorů, kteří jsou v této záležitosti zastupováni agenturou DILIA. Více o projektu na www.classcis.phil.muni.cz/darmojed. 
Interdisciplinární překladatelský tým (odbornice na archaickou latinu, na římské divadlo a odborník na římské právo) se při převodu antických reálií spolehl na několik dramaturgických postupů: některé aspekty římského života, v původním textu jen naznačené, jsou poněkud rozvedeny, aby byly srozumitelné i recipientovi neznalému antických reálií, jiné byly substituovány (tak se do překladu např. dostalo „takové dobré falernské“ víno) a další ve svých výstupech vysvětluje Referencie Podčarová, dopsaná postava personifikované poznámky pod čarou.

Mluvnost a dramatické kvality předkládaného scénáře byly v praxi ověřeny inscenací textu v rámci semináře ÚKS FF MU, kterou připravili překladatelé textu spolu se studenty zmíněného ústavu a Katedry divadelních studií, hudbu k některým z písní (píseň stařeny Castorie, verše 96-108, a Romantikova píseň k závoře, verše 147-152) složil hudební skladatel Miloš Štědroň. Inscenace měla premiéru 24. ledna 2018 v Univerzitním kině Scalaa aktuálně (ř́ijen 2018) již proběhlo celkem jedenáct repríz (např̀. na Dni s překladem Ostravské univerzity, na letní škole klasických studií v Kuksu, v klášteře v Broumově, na festivalu barokního divadla v Mikulově a také pro brněnská gymnázia).

\section{Literatura:}

PLAUTUS, Titus Maccius. 2008. Curculio. Septimio Lanciotti (ed.). Urbino: QuattroVenti, 2008. PLAUTUS, Titus Maccius. 2011. Casina, The Casket Comedy, Curculio, Epidicus, The Two Menaechmuses. Wolfgang de Melo (překl. a ed.). Cambridge, Mass.: Harvard University Press, 2011. Loeb Classical Library.

POLÁČKOVÁ, Eliška. 2016. Stereotypy v českých překladech Tita Maccia Plauta. In Jakub Čechvala, Eliška Poláčková et al. Ve stínu hellénského slunce. Obrazy antiky v moderni české kultuře. Praha: Nakladatelství Filosofia, 2016: 243-316, 339-410.

URBANOVÁ, Daniela, Tomáš WEISSAR, Radek ČERNOCH a Eliška POLÁČKOVÁ. 2018. Několik poznámek k českému překladu Plautovy komedie Curculio. In J. Balegová, E. Brodňanská, F. Šimon (edd.). Hortus Graeco-latinus Cassoviensis II. Košice: Univerzita Pavla Josefa Šafárika v Košicích, FF Katedra klasickej filológie, 2018: 241-257. 


\section{Obsah}

Romantikus posílá Darmojeda do Megalopole opatřit peníze, aby mohl vykoupit svou milou od kuplíre. Darmojedovi se tam podaří připravit Romantikova soka, vojáka Gaia Omnibuse Pacona, o pečetní prsten, kterým pak zapečetí dopis pro bankéře Hypotéka. Jakmile bankéř Hypotékus uvidí dopis, pozná vojákovu pečet a zaplatí kuplíri, aby propustil Romantikovu dívku Errotium. Podvedený voják žene bankéře i kuplíře k soudu. Pak ale zjistí, že dívka Errotium, k níž zmírá láskou, je jeho vlastní sestra. Nakonec tedy podlehne jejím prosbám a dá ji za ženu Romantikovi.

\section{Osoby}

Otrok Sofistikus (Palinurus), patří mladíkovi Romantikovi

Mladík Romantikus (Phaedromus), bezhlavě zamilovaný do dívky Errotium

Stařena Castoria (Leaena), zaměstnankyně kuplírova podniku

Dívka Errotium (Planesium), v majetku kuplíře, ale stále panna

Kuplír Pornotékus (Cappadox), těžce nemocný

Kuchař, pracuje pro Romantika

Příživník Darmojed (Curculio), Romantikův parazit

Bankéř Hypotékus (Lyco), lichvář

Chorégos, produkční

Voják Gaius Omnibus Paco, řečený Poclusemclus (Therapontigonus Platagidorus), Romantikův sok, zamilovaný do dívky Errotium

Referencie Podčarová, personifikovaná poznámka pod čarou (dopsaná postava)

\section{Dějiště}

Ulice v Epidauru. Uprostřed stojí chrám Asklépia. Nalevo je dům kuplíre. Před ním stojí oltář bohyně Venuše. Napravo od chrámu je dům mladíka Romantika. Směrem doprava vede ulice dále na fórum, doleva naopak z města ven. 


\section{Dějství první ${ }^{2}$}

Potemnèlá scéna. Romantikus vycházi ze svého domu v průvodu otroků, za nimi jde Sofistikus. Romantikus drži svičku, jeden z otroků džbán. Hraje „strašidelny“ svatebni pochod.

POZN. (prereruši tajemnou atmosféru) Pardon, ještě než začneme, s dovolením bych $\mathrm{k}$ tomu řekla pár slov. Víte, už mě nebaví, jak mě lidé pořád ignorují. Jako bych vůbec nebyla. A přitom říkám samé zajímavé a důležité věci... Abyste rozuměli, já jsem Referencie Podčarová, tedy poznámka pod čarou, a budu vás provázet tímto dramatickým kusem, abyste všemu dobře rozuměli. Tak předně vás musím upozornit na scénografii, tedy na to, co vidíte na scéně. Jedná se o kulisy pro ř́mskou komedii naprosto typické - v pozadí stojí tři domy, z nichž prostřední je chrám, v našem př́ípadě boha Asklépia, patrona lékařství. Napravo od něho je dům mladíka Romantika, nalevo pak dům kupliŕưv. Před jeho dveřmi stojí oltář bohyně Venuše. Odchází-li někdo ze scény vpravo, víme, že směřuje na fórum, nalevo pak z města ven. A nyní alespoň stručně ke hře, kterou uvidíte. V originále se jmenuje Curculio a napsal ji kolem roku 200 př. n. 1. římský dramatik Titus Maccius Plautus. Ten se narodil pravděpodobně...

SOF. (přeruši ji) Ehm, děláš si srandu?

POZN. No dobře, dobře. Více o Plautově životě a díle viz Conte, Gian Biagio. Dějiny římské literatury. Praha: Koniasch Latin Press, 2008, s. 57-69. (scéna pokračuje dál) ${ }^{3}$

SOF. Romantiku, můžeš mi říct, kam se to jako chystáš jít? Ted'v noci, v těchhle šatech... A s celým tímhle procesím?

ROM. Tam, kam Venuše a Cupido mi velí, sama Láska káže. At̉ už je hluboká noc, nebo časné ráno, at si vím třeba měsíc předem, že mám stání u soudu, já prostě musím chtě nechtě jít tam, kam mě srdce táhne.

SOF. Ale...

ROM. Dej mi pokoj s tím svým věčným „ale“!

SOF. Ale tohle je absolutně nevhodné. Copak se sluší, aby sis, pane, sám sobě svítil na cestu svíčkou jako nějaký otrok?

10 ROM. A proč bych sám sobě nemohl nést svíci? Je z vosku - to dílko pilných včeliček, stejně jako slad'oučký med, a já jdu přece ke své nejsladší.

SOF. Kam že to jdeš?

ROM. Na tuto tvou otázku ti, milý Sofistiku, rád odpovím.

SOF. No, tak mi odpověz!

ROM. Tady tohle je Asklépiův chrám.

SOF. No, to jsem teda fakt nevěděl.

2 Překlad vychází z edice latinského textu hry sestavené Septimiem Lanciottim, s přihlédnutím k edici Wolfganga de Mela a dalším edicím a komentářum.

3 Svislou boční čárou jsou vyznačeny moderní dodatky k původnímu přeloženému textu. Čísla na boku označují verše v původním textu. 
ROM. A tady hned vedle jsou dveře mé nejmilejší... Bud'te zdrávy, ó dveře nejnádhernější, jak se vám daří?

SOF. Bud'te zdrávy, ó dveře nejzavřenějšíi, doufám, že vás včera neofouklo a že ted' nemáte rýmičku. A copak dobrého jste měly včera $\mathrm{k}$ večeři?

ROM. Děláš si ze mě srandu?

SOF. Tak proč se, ty blázne, vyptáváš dveří, jak se jim daří?

20 ROM. Protože tohle jsou, u Herkula, ty nejkrásnější a nejtišší dveře, co jsem kdy viděl! Nikdy ani nehlesnou. Potichoučku se otvírají, když mou milou tajně pouští za mnou ven. Ani hlásku nevydají.

POZN. Tohle je mladík Romantikus - v originále Phaedromus adulescens. Jak si můžete povšimnout, je to mladík zamilovaný, jak už to tak v plautovské komedii bývá. Smůla ovšem je, že se většinou zamiluje do nesprávné ženy, totiž do prostitutky. Situace se dále komplikuje tím, že si na jeho milou obvykle dělá zálusk někdo jiný většinou o dost mocnější a movitější. Ze zdánlivě bezvýchodné situace však mladíka vysvobodí úžasný a nepřekonatelný Sofistikus - původním jménem Palinurus, servus callidus, neboli chytrý otrok, spíš bychom ale řekli lstivý, prohnaný, všemi mastmi mazaný podšívka a vykuk, který - jak to o pár století později skvěle pojmenoval Carlo Goldoni - slouží dvěma pánům zároveň. Tedy - ne v téhle hře... Ale často. $\mathrm{V}$ naší hře vlastně zas až tak prohnaný není. A mladík si v ní $\mathrm{k}$ dívce svého srdce nakonec pomůže víceméně sám. No... Jak vidíte, s otroky to u Plauta není zrovna jednoduché. Radši se pojd’me podívat, jak to bude dál.

SOF. Pane! Nechystáš se doufám spáchat nějakou hanebnost, která se zásadně neslučuje s tvým původem a postavením! Doufám, že nemáš políčeno na nějakou počestnou dívku! Nebo na nějakou, co by alespoň počestná být měla...

ROM. To bych si, přísahám bohům, nedovolil!

SOF. To bych ti radil! Kdo má za ušima, ten dobře ví, že v milostných avantýrách je hlavní nedostat se do potíží, a dává si vždycky pozor, aby nepřišel o svědky.

ROM. Jak to myslís?

SOF. Prostě bud' opatrný a užívej si jen v přítomnosti svědků.

POZN. Moment, prosím vás, vždyt to vůbec nedává smysl. Vy jste zjevně nepochopili tu Plautovu slovní hříčku, že?

SOF. No, neříkám, že se mi to nezdálo nějaké divné...

POZN. Takže krátká lekce latiny - testes jsou sice svědkové, ale taky, no, chápete... (Romantikus Sofistikovi naznačuje, že se jedná o mužské pohlavni orgány)

SOF. Aháá, už chápu!

POZN. A jde o to, že ztrátou dobré pověsti přichází římský občan také o možnost dožadovat se něčího svědectví u soudu - stává se v právnické terminologii intestabilis. To slovo ovšem také může znamenat, že je, ehm, jaksi tělesně indisponován... (Romantikus posunkem naznačuje kastraci)

SOF. No to je ovšem genitální dvojsmysl! Tak já to zkusím ještě jednou, jo? 
ROM. To bych si, přísahám bohům, nedovolil!

SOF. To bych ti radil! Kdo má za ušima, ten dobře ví, že v milostných avantýrách je hlavní nedostat se do potíží, a dává si vždycky pozor, aby mu někdo neuřízl... Totiž aby si neuřízl ostudu.

ROM. Jak to myslís?

SOF. Prostě bud' opatrný. Na to, aby sis mohl jen tak mir nichts dir nichts užívat, na to holt musís mít koule.

ROM. Ale tady bydlí kuplír.

SOF. Tak to pak beze všeho. Nikdo ti přece nemůže bránit koupit si něco, co je volně k mání, když na to máš. Stejně jako nemůže nikdo nikomu zakazovat, aby chodil po veřejné ulici, dokud si ovšem nezačne prošlapávat cestičku do cizí zahrádky za plotem. Když nebudeš mít pletky s vdanou, vdovou nebo s pannou, s mladistvými pod zákonem nebo s chlapečkama, užívej si, s kým chceš.

ROM. Ale vždyt říkám, že je to dům kuplí-

40 SOF. K čertu s ním!

ROM. S kým zas?

SOF. S tím odporným pelešnickým doupětem!

ROM. Jasně, jen mi pořád skákej do řeči!

SOF. Beze všeho, jak je libo.

ROM. Tak budeš už zticha!?

SOF. $\quad$ Ale vždyt jsi říkal, pane, že ti mám skákat do řeči.

ROM. No tak ted' ti to zakazuju! Abych to teda konečně dořekl, tomu kuplíři tady patří ta dívenka... Errotium se jmenuje!

SOF. Hmmm, Erotium...

POZN. S dvěma r! Od slova error, ne eros!

ROM. Chce z té dívky udělat děvku.

SOF. Jako ten kuplír?

ROM. Ted' jsi na to kápl!

SOF. Tak to abych to utřel.

ROM. Fakt mi lezeš na nervy! Bláznivě mě miluje...

SOF. Ten Kuplíŕr?!

ROM. Né, probohy, přece ona, ta dívka, Errotium.

SOF. Nějak se v tom začínám ztrácet. No, každopádně tajné milostné pletky, to je učiněná pohroma.

50 ROM. Přesně, jak ř́káš.

SOF. Hele, a už jsi s ní něco měl? Už je ruka v rukávě?

ROM. Kdepak, ani jsem se jí nedotkl! Je čistá jako lilium. Teda leda že by přišla trošičku $\mathrm{k}$ úhoně tím pusinkováním... 
SOF. Pamatuj si! Není kouře bez ohně. Od kouře se nespálíš, ale s ohněm si není radno zahrávat. Kdo si chce smlsnout na mandličce, počítá s louskáním. No a kdo chce do postele, začíná líbáním.

ROM. Ale moje Errotium je ještě panna, s nikým nic nemá! Ani neměla!

SOF. No jasně, jako každá holka v bordelu.

60 ROM. Co si to o ní myslís? Vždycky, když se potajmu setkáme, sotva mě políbí, hned zase uteče. A za to všechno může ten kuplír, co ted' chodí přespávat do Asklépiova chrámu a myslí si, že mu bůh lékařství vyléčí revma. Grázl jeden!

SOF. Proč grázl?

ROM. Protože za ni chce děsnej balík - třicet min - a nic s ním nehne. Když se snažím smlouvat, chce ještě víc.

SOF. A cos čekal od kuplíře? Nějakou akční nabídku? Kde to žiješ?

ROM. Už jsem poslal Darmojeda do Megalopole za jedním svým dobrým př́itelem, aby mi půjčil. Jestli se ale vrátí bez peněz, tak už vážně nevím, kam se obrátím.

70 SOF. $\quad$ Radil bych doprava, když tě smrtelníci nechali ve štychu.

ROM. Máš pravdu, Sofistiku, tady má přece oltář bohyně Venuše, které jsem slíbil obětovat snídani.

SOF. Cože? Ty jí chceš obětovat svoji snídani?!

ROM. (ironicky) Jasně, moji, tvoji a všech tady těch! (ukazuje do publika)

SOF. Chceš, aby chudinka Venuše hodila šavli?

ROM. (na otroka) Chlapče, podej mi ten džbán.

SOF. $\quad$ Co chceš dělat?

ROM. Uvidíš. Za těmi dveřmi pospává na stráži stará vrátná, co si moc ráda přihne vína - a nejradši neředěného. Jmenuje se Castoria.

SOF. Cože, Chlastoria?

ROM. Máš pravdu, to by sedělo víc. No prostě je to opravdu veliká milovnice vína. Stačí jen lehce pokropit dveře a ona hned zavětří, že jsem tady, a přijde mi otevřít.

SOF. Takže ten džbán vína, co neseme, je pro ni?!

ROM. Máš snad zase něco proti?

SOF. No to teda mám! To jsme ho rovnou mohli vylít do kloaky! Já myslel, že je to pro nás.

ROM. Nech toho remcání. Třeba nám něco nechá.

SOF. Ta určitě. Vždyt je jako bezedný sud!

ROM. Hele, pojd' radši se mnou k těm dveřím a dělej, co říkám.

SOF. K vašim službám, pane.

ROM. Jen si dejte, milé dveře, napijte se na zdraví - a nezapomínejte, kdo vám tohle dobré víno nosí! (kropi dveře vínem)

90 SOF. Dáte si k tomu vínu olivy, nebo třeba kaviár? A co takhle tuřín? Ten je prej dobrej na kocovinu...

ROM. Probud'te svou strážkyni, ó dveře, at přijde mi sem otevřít. 


\section{Curculio aneb Darmojed}

SOF. Pošlete mu sem už konečně toho svýho Kerbera, co vás hlídá líp, než kdyby tudy vedla cesta do Hádu...

POZN. To tam není!

SOF. No jo, pardon, nechal jsem se trochu unést. Ale hodilo by se to tam, ne? Mýty, báje, antika... Už mlčím.

(na Romantika) Co bláznís? Nelej to tam všechno!

ROM. Nerad'. Vidíš, jak se ty překrásné dveře pomalounku potichounku otvírají? Taková nádhera!

SOF. Jenom čekám, kdy je začneš líbat...

ROM. Sklapni! A zhasni!

SOF. No jo.

Vzdáli se a pozoruji Castorii, která vycházi z kuplírova domu, leze po čtyřech a čenichá.

CAS. (zpěv) Slad’oučký odér vinného moku mě pod krkem chytil a ke dveřím táhne.

Kdepak tě, vínečko, rozmilé mám?

Tady jsi! Zdráv mi bud', Bakchu, můj pane.

100

Jsem zralá jako ty - krásný jsme pár!

Ty jsi mi dražší než nejdražší zboží,

zářîš jak rubín a vůní překonáš vanilku, myrtu, šafrán i růži.

Chci, abys zkropilo jednou můj hrob -

Proč vůbec marním tu čas s nosem u pasu?

Chci si dát konečně pořádně do nosu!

Apage, mámení! Kdepak jsi, broučku?

Lahvinko, pojd' ke mně, spojme svá hrdla,

at víno proteče ze dna - až do dna.

Ha, tady cítím stopu, tudy to vezmu.

110 ROM. Ta stařenka má malinko žízeň.

SOF. Jak moc malinko má žízeň?

ROM. Nepřehání to, stačil by jí jeden sud.

SOF. Jak tě tak poslouchám, spíš bych řekl, že by zvládla vypít na ex celý vinný sklípek! A jaký má na to víno čuch! Kam se na ni hrabe kdejaký pes.

CAS. Haló! Kdo to tady mluví? (šourá se po scéně opačným směrem)

ROM. Myslím, že bych se jí měl ozvat. Jdu za ní. Pojd’ zpátky, Castorie, na mě hled"

CAS. Kdo mi to poroučí?

ROM. To jsem já, tvé rozmilé vínečko, tvůj pán Bakchus. Jen pojd’ a napij se, své vyschlé hrdlo svlaž, probud' své smysly a utiš tu palčivou žízeň...

CAS. Kde je, kde je to víno? 
ROM. Jdi za svitem svíce.

120 CAS. Zapřísahám tě, přistup blíže.

ROM. Bud' zdráva!

CAS. Jak mám jako být zdravá, ved' smädná som ako tava!

ROM. Neboj, už to bude, hned se napiješ.

CAS. Včera bylo pozdě!

ROM. Dejte si, milá dámo. (podává ji amforu)

CAS. Na zdraví, můj nejmilejší!

SOF. No honem, tak už to tam kopni, nádobo bezedná. Vrchem dovnitř a spodem ven a hlavně se z toho ne... nezalkni!

ROM. Bud' z ticha! Neř́kej jí nic ošklivého!

SOF. Tak jí mám rovnou něco ošklivého udělat?

CAS. Ó vznešená Venuše, z toho mála, co sama mám, malinko ti sem uliju - ovšem dost nerada. (ulévá na oltář víno) Protože tobě všichni milenci, co stejně pořád jen popíjejí, ulívají, aby si tě naklonili. Kdežto mně hned tak někdo... nenaleje. (začne hltavě pit)

SOF. Jen se podívej, jak to ta babizna do sebe klopí, div se nezalkne. Takové dobré falernské...

ROM. Sakra, jsem v háji! Nevím, jak jí to mám říct.

SOF. Tak, jak jsi to ted' řekl mně.

130 ROM. Co?

SOF. No, že jsi v háji.

ROM. Ale sám běž do háje!

SOF. No tak, řekni jí to...

CAS. Áááa!

SOF. Tak co? Chutnalo? Spokojená?

CAS. Jo.

SOF. Taky bych byl spokojený, kdybych ti ted' mohl jednu vrazit!

ROM. Bud' zticha!

SOF. Au! Už mlčím... Ale vážně pije jako duha, co? A přitom ani nekáplo. (pohlédne pod Castorii) Zatím...

ROM. Tak mám jí to teda říct?

SOF. Co jako?

ROM. Že jsem v háji.

SOF. Jen do toho!

ROM. Poslyš, Castorie, musím ti něco říct. Jsem ztracen.

CAS. Zato já už jsem se našla... A jakpak to, mladý pane?

ROM. Protože nemůžu být se svou milovanou. 
CAS. Ale no tak, mladý pane, nechte toho fňukání. Postarejte se radši, abych měla co pít, a já vám přivedu tu slečinku, bez které tak nemůžete být. (odcházi zpět do kuplírova domu)

140 ROM. Ó paní, jestli dodržíš svůj slib, révovou sochu dám ti postavit!

Pomník z vypitých amfor at navěky všem hlásá:

víno je paní Castorie jediná láska a spása!

Vždyt kdo na světě bude štastnější než já,

přijde-li konečně za mnou má jediná!

Co ř́káš, Sofistiku?

SOF. $\quad$ No jo, když je někdo zamilovaný a bez peněz, to je holé neštěstí.

ROM. Tak to se pleteš. Dnes už určitě dorazí zpátky Darmojed i s penězi, pro které jsem ho poslal.

SOF. Ten a s penězi? Četl jsi někdy Plauta?

POZN. Postava parazita neboli příživníka je v římské komedii notoricky závislá na svém patronovi. Že by parazit získal nějaké peníze (zpraži Romantika pohledem), je krajně nepravděpodobné.

ROM. A co kdybych šel k těm dveřím a zkusil je očarovat?

SOF. Jestli chceš, já ti bránit nebudu, pane. Jen žasnu nad tvou morální proměnou. Tobě snad přeskočilo?

ROM. (zpivá u dveři kuplírova domu)

Závoro, závoro, zdravím tě uctivě,

rád tě vidím, rád tě mám!

Prosím tě, žádám tě, zapřísahám:

Závoro ty nekrásnější,

s láskou mojí soucit měj,

150 kvưli mně se rozhoupej,

vyskoč z pantů, hned ted' povol,

mojí milé ke mně dovol.

Já bez ní nemůžu být...

Jen se podívej, jak tvrdě spí, závora zatracená! Má úpěnlivá prosba s ní ani nehne. Vidím, závoro, že si mé úcty k tobě ale vůbec nevážíšs! Pst, tiše!

SOF. No, já jsem ticho celou dobu.

ROM. Něco slyším. Že by mě přece jen ta závora vyslyšela?

Opět se vzdálí. Z kuplírova domu vycházi Castoria.

CAS. Tak pojd', má milá, ale hlavně potichu. Opatrně otvírej ty dveře a pozor na panty, at̉ nevrznou! Ještě by se pán mohl dozvědět, co tu provádíme. Počkej, trošku je radši přimáznu. (polévá pant vodou) 
SOF. Jen se podívej, jak to té staré bábě s Parkinsonem pálí! Sama ví, že když se namaže, všechno jde hladce. A s dveřmi je to zrovna tak. (Castoria mezitím odcházi zpět do kuplírova domu, vycházi Errotium)

POZN. Tak to je ta Romantikova vyvolená - Errotium - u Plauta se jmenuje Planesium, což by se dalo přeložit jako „malá tulačka“, proto Errotium s dvěma $\mathrm{r}$ - neplést! Bydlí sice u kuplíře, takže by člověk řekl, že bude poskytovat... jisté služby a že nebude svobodná Ř́manka, nýbrž otrokyně. V plautovské komedii se ale vždycky nakonec ukáže, že dívka je svobodného původu, jen ji v dětství unesli piráti, ztratila se při ztroskotání lodi, zř́ítilo se lešení nebo jiná podobná katastrofa - následkem čehož se dostala do domu kuplíre, který s ní ovšem nakládá s neobvyklou jemností. Dívka je tedy i po letech pobytu v bordelu stále panna a zamilovaný mladík si ji podle římských mravů může vzít za ženu.

ERR. Tak kdepak jsi, kdož jsi mě dal předvolat k tomu dnešnímu stání? Že prý když se nedostavím, sama Venuše mě odsoudí. Tak jsem se tedy dostavila, a kde jsi ty? Proč se také nepo... nedostavíšs?

ROM. (volá na ni zpovzdálí) Už stojím, má drahá, a kdybych nestál, bylo by to trestuhodné.

ERR. Ale to je nepř́ípustné, abys stál... tak daleko ode mě, můj milý. Jen pojd’ blíž.

ROM. Ach, Sofistiku!

SOF. Proč mě voláš, pane?

ROM. Není překrásná?

SOF. Vskutku překrásná.

ROM. Cítím se jako bůh.

SOF. A přitom jsi prachobyčejný smrtelník.

ROM. Viděl jsi snad či uvidíš-li kdy stvoření krásnější, bohům podobnější?

SOF. Neviděl... Zato s lítostí pozoruji, že ty nejsi zcela při smyslech.

ROM. Otroku nejapný, radši mlč!

170 SOF. Jen blázen stojí na místě, místo aby objímal svou milou, když už konečně může.

ROM. Má pravdu! Vždyt skutečně není nic, po čem bych celou tu dobu toužil víc!

ERR. No tak mě přece obejmi!

ROM. (konečněji obejme) Pro tohle jediné stojí za to žít! Když nám tvůj pán brání, abychom byli spolu, vezmu si tě tajně.

ERR. Že nám můj pán brání? Nebrání a nezabrání! Nás rozdělí jedině smrt!

SOF. $\quad(k$ publiku) Nemějte mi to za zlé, vážení, ale ten můj pán se vážně zbláznil! Milovat se musí s mírou, prostě jen tak akorát - to se nemůže nic stát. Ale samou láskou bláznit - to nemůže dobře skončit. A můj pán už zjevně samou láskou přišel o rozum.

ROM. At̉ si králové mají svá království, at si boháči nechají své bohatství, své zásluhy, čest, 180 slavná vítězství. Dokud mně nikdo nezávidí, každému, co jeho jest.

SOF. Nerad ruším, pane, ale jestli ses nerozhodl dělat Venuši noční ostrahu, měli bychom už jít. Co nevidět bude svítat.

ROM. $\quad \check{S} \check{s ̌ s ̌ s ̌ . . . ~}$ 
SOF. Jaképak šššš? Ty jako nehodláš jít spát?

ROM. Já spím, tak neruš.

SOF. Ale ty nespís.

ROM. Ale to víš, že spím. A sním svůj sladký sen... (oba jsou stále v objetí)

SOF. Slečinko, to se nedělá, chovat se takhle nevhodně k někomu tak hodnému.

ERR. Kdyby ses chystal jíst a někdo by ti sebral jídlo rovnou z talíře, taky by ses zlobil.

SOF. Tak to je konec... Jak tak koukám, jsou v tom oba až po uši a nehledí napravo ani nalevo, jako by se pomátli. No jen se podívejte, jak se samou láskou rozplývají. Už se skoro ani v objetí neudrží... Tak jdete už od sebe!?

190 ERR. Žádné lidské štěstí není dokonalé. To naše zkrátka kazí ten protiva. (pohodí hlavou směrem ke kuplírovu domu)

SOF. Cos to řekla, ty nestydo? Co mi máš co říkat „protiva“, hampejznice jedna? Ty vyzáblá násosko! Ty komediantko!

ROM. Tak ty budeš nadávat mé Venuši? Nějaký špinavý otrok si tady na mě bude vyskakovat?

SOF. Na tebe, snad na ni, ne?

POZN. Neslyšel jsi nikdy o zprostředkované urážce? V Římě to byla běžná praxe.

ROM. Tak to ne! No počkej, tohleto si šeredně odskáčeš! To máš za ty svoje řeči, aby sis př́šstě dával pozor na jazyk! (bije ho)

SOF. (schovává se za Errotium) Pomoc, ó „Venuše“, patronko flámů!

ROM. Tak ty si nedáš pokoj, darebáku?

ERR. Nech ho. Vždyt je to jak mlátit prázdnou slámu.

SOF. Dopouštíš se neskonalé ničemnosti, pane! Nejenom, že se tajně scházíš s touhle 200 hloupou husou, ale ještě mě biješ. Mě, který ti tak dobře radí. Je vůbec možné, aby ses choval tak nerozumně?

ROM. Ukaž mi někoho, kdo je zamilovaný a chová se přitom rozumně, a dám ti tolik zlata, kolik sám váží.

SOF. To já bych dal klidně celé zlaté rouno, kdybych mohl místo tebe sloužit někomu normálnímu.

ERR. Sbohem, má lásko, slyším, jak rachotí závora chrámových dveří. Strážce už se je chystá otevřít. Řekni, jak dlouho ještě budeme muset naši lásku ukrádat takhle po nocích?

ROM. Už dlouho ne! Před třemi dny jsem poslal Darmojeda do Megalopole pro peníze, dnes už bude určitě zpátky.

ERR. I „dlouho ne“ je moc dlouho!

ROM. Jak je Venuše nade mnou, přísahám, že tě nenechám v tomhle domě už ani den a budeš konečně svolná... totiž volná.

210 ERR. Jen abys na tu svoji př́ísahu pamatoval. Tady máš ještě hubičku, než půjdu.

ROM. Při bozích, i kdyby mi nabízeli vládu nad celým Římem, za tebe bych ji nikdy nevyměnil. Kdy tě zas uvidím? 
ERR. Jestli mě opravdu miluješ, tak splň, co jsi slíbil. Přestaň chodit kolem horké kaše a prostě si mě kup. A ne aby tě někdo přeplatil! Pá! (odcházi zpět do kuplírova domu)

ROM. Tak jsem zas sám a touhou umírám...

SOF. Jestli tu někdo umírá, tak jsem to já! Zmlácený a nevyspalý!

ROM. Jdeme. (oba odcházeji i s otroky do Romantikova domu)

\section{Dějství druhé}

Rozedni se. Z Asklépiova chrámu vychází kupliŕ.

POZN. A tady máme první zápornou postavu hry - kuplíŕe Pornotéka. V originále se jmenuje Cappadox, protože Kappadokie, bývalá římská provincie v dnešním Turecku, byla v Plautově době proslulá jako zásobárna kvalitních... eee... otroků určených pro... no... lupanária... To si dohledejte. Kuplíře nemá v plautovské komedii nikdo rád a bývá vykreslený v těch nejčernějších barvách. Ostatně, přesvědčte se sami.

PORN. Rozhodl jsem se, že v tomhle chrámu nezůstanu už ani minutu. Asklépios mi dal dost jasně najevo, že mu na mně nezáleží a nehodlá mě uzdravit. A mně zatím ubývá sil a přibývá kil. Slezina mě tlačí jak utažený opasek a břicho mám, jak kdybych čekal dvojčata. Mám pocit, že co nevidět prasknu.

SOF. (vycházi z Romantikova domu, mluvi k Romantikovi, který je uvnitř) Udělal bys nejlépe, pane, kdybys dal na mě a přestal se bát, že se Darmojed z Megalopole nevrátí. Podle mě ty peníze donese. A i kdyby ne, vrátí se určitě - ani rozžhaveným železem by ho nikdo nepřinutil, aby se dobrovolně vzdal svého koryta.

PORN. Kdo to tady mluví?

SOF. Koho to tu slyším?

230 PORN. Není to Sofistikus, Romantikův otrok?

SOF. $\quad$ Co je to tu za chlápka? Břicho má jak bečka, žlutý je jak papyrus... To břicho je mi povědomé, ale ta barva mě nějak mate. Už vím! Vždyt je to kuplíř Pornotékus. Půjdu za ním.

PORN. Bud' zdráv, Sofistiku.

SOF. $\quad$ No spíš ty bud' zdráv, ty starej prasáku. Jak se vede?

PORN. Ještě žiju.

SOF. A koukám, že tak, jak si zasloužíšs. Co je s tebou?

PORN. Ále, ta slezina mě asi brzo zabije. Berou mě ledviny, plíce se mi můžou rozervat, játra mám v sakrech, srdce na dranc a do střev mě berou křeče.

SOF. To vypadá na pořádnou cirhózu.

240 PORN. No jen se posmívej nemocnému člověku. 
SOF. Hele, dej na mě. Počkej ještě pár dní, co ti ty střeva úplně vyhnijou, a můžeš na nich pěkně vydělat. Vem si takový garum, tu omáčku. To jsou v podstatě shnilý ryby, a jak jdou na dračku! Říkám ti - to bude nakonec to nejlepší, co v tobě je.

PORN. Při Herkulovi, ta slezina, to bude moje smrt!

SOF. To bude nejlepší... když se půjdeš projít. Procházky jsou na slezinu to nejlepší.

PORN. Už toho nech, prosímtě, a radši mi řekni: když ti povím, co se mi dnes v noci zdálo, uměl bys mi to vyložit? (ve dveřich Romantikova domu se objevi kuchař)

SOF. No ovšem! Ten nejlepší vykladač božských úradků stojí přímo před tebou. Vždyt 250

KUCH. No tak, Sofistiku, co tady obejduješ? Jak mám podle tebe vařit Darmojedovi na uvítanou, když jsi mi ještě nic nedonesl?

SOF. Hned to bude, jen co tady tomu vyložím sen.

KUCH. Ty? No hlavně že když se něco zdá tobě, utíkáš vždycky pro radu za mnou.

SOF. No to je fakt.

KUCH. Neříkal jsem ti, že mi máš něco donést?

SOF. Tak zatím řekni ten svůj sen jemu. Přenechám tě schopnějšímu vykladači. Všechno, co vím o snech, mám od něho.

PORN. Jen aby se dost snažil.

SOF. To on bude. (odcházi do města)

PORN. To už se dnes jen tak nevidí, aby si někdo tak vážil svého učitele. No tak mě poslouchej.

KUCH. Poslouchám. Sice to normálně nedělám, ale pokusím se.

260 PORN. Dnes v noci se mi zdálo, že se mi ve snu zjevil Asklépios. Seděl daleko ode mne a zdálo se mi, že ke mně nejde a že mu na mně vůbec nesejde.

KUCH. A ostatním bohům jakbysmet - ti vždycky drží basu. Není divu, že je ti čím dál tím hůř. Spíš než k Asklépiovi bys měl jít nocovat do chrámu Jova Kapitolského (ironicky) ten přece bdí nad sliby všech počestných kuplírů.

PORN. Pche, kdyby všichni, kdo kdy křivě př́ísahali, chodili spát k Jovovi do chrámu, tak by se na Kapitol ani nevešli.

270 KUCH. Dej na mě, hled’ si usmírit Asklépia, jinak se od tebe bude zdraví dál držet v uctivé vzdálenosti, zrovna jako on v tom tvém snu.

PORN. Máš pravdu, hned se půjdu modlit. (odcházi zpět do chrámu)

KUCH. Hodně neštěstí! (odcházi do Romantikova domu)

SOF. (vraci se $z$ města) U všech bohů všemohoucích! Není možná! Nevrací se támhle Darmojed z Megalopole? Hej, Romantiku, pojd' sem, no honem, pospěš si!

ROM. (vycházi z domu s několika otroky) Co tady tak hulákášs?

SOF. Darmojed je tady, už běží, hele, támhle je, na konci ulice! A něco křičí. Pst, at ho slyšíme!

ROM. Dobrý nápad. 
Objevi se Darmojed, utiká, lape po dechu.

280 DAR. (zpěv) Z cesty, všichni, velký úkol mám,

hni se, každý, at̉ ho znám, neznám,

ten, kdo stát zůstane, hrozí mu, že dostane,

hlavou, loktem, kolenem - ránu jako polenem.

Zčistajasna jsem do toho spad,

jen si zkuste v cestě mi ted' stát,

generál, inspektor, starosta či primátor,

všichni skončí postupně - hlavou dolů v př́kopě. ${ }^{4}$

(recitativ) A tihle Řekové, co si tu vykračují navlečení do pallia s plachetkou na hlavě, plná náruč knih a košíček s jídlem, ti přivandrovalci, co věčně někde postávají, diskutují, vedou dialogy, motají se, překážejí v cestě, jak pávi se nesou $\mathrm{s}$ těmi svými moudry. Přitom je věčně vidíš nasávat někde v pajzlu, jen co něco ukradnou. Vysedávají tam v těch svých plachetkách, popíjejí svařák a pak se nadraní s mrzutým výrazem motají po ulici... Jestli já do někoho z nich narazím, tak to ode mě schytá, až ducha vypustí - pěkně smrdutýho! A běda, jestli mi přijde do cesty nějaký ten povaleč nebo jeho otroci, co si hrajou na ulici s míčem. Útočník nebo obránce, je mi to jedno, všechny je zadupu do země! Takže jestli nechcete, aby se vám něco stalo, radši zůstaňte pěkně doma!

300 ROM. Dobře to říká, jenže s tím nic nezmůže. S těmi otroky je to ted' čím dál horší. Jsou jako utržení ze řetězu.

POZN. A konečně s velkou slávou přichází hlavní postava hry - Curculio, v našem překladu Darmojed. Ovšem najít adekvátní překlad tohoto jména je pravděpodobně nemožné. Označuje totiž brouka z čeledi nosatcovitých, který byl pro Římany obávaným parazitem, a skvěle tedy vystihovalo tuto typizovanou postavu - parazita. Parazit je vlastně klient svého patrona, propuštěný otrok nebo chudý Říman, který je závislý na dobročinnosti svého ochránce. V plautovské komedii bývá většinou dosti nesympatickou postavou a zajímá ho zpravidla jen to, kde a jak se co nejlépe a hlavně zadarmo najíst. Ale ve hře Curculio je naopak ústředním hybatelem děje a přebírá funkci chytrého otroka.

DAR. (udýchaně do publika) Lidi, kdo mi řekne, kde najdu Romantika, svého nebeského dobrodince? Strašně to spěchá, musím s ním okamžitě mluvit!

SOF. Shání se po tobě, pane.

ROM. Tak co mu jít naproti? Haló, Darmojede, taky s tebou chci mluvit.

DAR. Že bych zaslechl svoje jméno? Kdo mě to volá?

ROM. Někdo, kdo se s tebou moc chce setkat!

DAR. Určitě ale ne víc, než já s tebou!

4 Zpívá se na melodii brouka Kvapníka ze Včelích medvídki̊. 
ROM. Darmojede, má jediná naděje, co jsem se tě načekal, bud' zdráv!

DAR. I ty bud' zdráv, pane!

ROM. Jsem rád, že ses v pořádku vrátil. Podej mi ruku. Tak kde je moje záchrana? U Herkula tě prosím, mluv!

DAR. U Herkula, kde je moje záchrana? (začiná omdlévat)

ROM. Co je s tebou?

DAR. Temnoty mě obstupují, kolena se mi podlamují... jaký mám hlad.

310 ROM. Jejda, to bude asi únavou.

DAR. Drž mě, drž mě, prosím tě.

ROM. Podívejte, jak zbledl. Rychle mu přistrčte židli, at’ si může sednout, honem! A džbán s vodou! No tak!

DAR. Asi omdlím.

SOF. Chceš se napít vody?

DAR. Pokud v ní plavou játrové knedlíčky, tak sem s ní.

SOF. Do háje s tebou, fakt už!

DAR. Ach, jak já toužím po pravé vưni domova!

SOF. Není problém. (Sofistikus s otroky pouštěji vétry)

DAR. Ehm, co to jako děláte?

SOF. No, chtěl jsi přece cítit vůni domova.

DAR. Ale tohle není žádná vůně domova!

ROM. A co teda chceš?

DAR. No přece jíst a cítit vưni domácí kuchyně!

SOF. S Šlak aby tě trefil!

DAR. $\quad \mathrm{K}$ tomu nemám daleko! Zrak se mi kalí, na jazyku mám kopřivku a hroznou žaludeční migrénu k tomu. Po cestě mě postihl akutní nedostatek potravy, následkem čehož mám ted’ úplně prázdné břicho.

320 ROM. Neboj se, hned dostaneš něco k jídlu.

DAR. Něco! To je v mém stavu příliš vágní útěcha. Nemohl bys být trochu konkrétnějšíi?

SOF. Kdybys věděl, co všechno na tebe zbylo.

DAR. Chci, chci to vědět! A hlavně kde! Můj jazýček s tím vším neprodleně potřebuje něco osobně probrat!

ROM. Kýta, pajšl, vemínko, brzlík...

DAR. Všechno tohle, říkáš? (zklamaně) To možná tak pod zámkem někde ve špajzu.

ROM. Kdepak, všechno pěkně na mísách - nechal jsem to připravit, když jsem se dozvěděl, že přijdeš.

DAR. O tomhle se mnou nežertuj!

ROM. Je to pravda, jako že mě Errotium miluje - tak jako já ji! Ale pořád jsem se nedozvěděl, jaks pořídil.

DAR. Nic nenesu. 
ROM. Tak to je konec!

DAR. Ale ne, (podívá se jakoby na hodinky) vždyé jsme teprve v půlce... Potom, co jsem

330

ROM. To tě chválím!

DAR. Chválit mě můžeš, až se to, co bys rád, díky mně stane skutečností. Ted' pojd’me dovnitř zapečetit ten dopis.

ROM. Zdržuju to snad já?

DAR. Ale napřed si dáme něco na zub - kýtu, vemínko, brzlík... Kus chleba a opečený flák hovězího, to jednomu udělá dobře na žaludek. K tomu velký pohár a plný džbán, at máme jasnou mysl. Ty zapečetíš ten dopis, tenhle ti pomůže a já - já

ROM. Už jdu. (všichni odejdou do Romantikova domu) 


\section{Dějství třetí}

Směrem od města přicházi bankér̆ Hypotékus.

HYP. ̌ekl bych, že jsem za vodou. Právě jsem provedl průběžné vyúčtování - má dáti, dal, sečteno podtrženo - jsem boháč...

POZN. Postava bankéře je vedle kuplíře další zápornou postavou Plautových komedií. Je to bezskrupulózní, penězchtivý a namyšlený paňáca, který nemá problém bezostyšně přiznat, že mu jde jen a jen o to odírat svoje bezbranné věřitele. No, některé věci se zřejmě od Plautových dob moc nezměnily...

HYP. Takže jak jsem ř́ikal - jsem boháč. Tedy pokud nevrátím, co dlužím. Pokud vrátím, co dlužím, tak jsem ovšem v mínusu. Hrom aby do toho! Ale když nad tím tak uvažuju, jestli na mě budou ti dotěrové dotírat, půjdu za prétorem. V tom našem -

POZN. Promiňte, jen bych to ráda dovysvětlila - u prétora by mohl bankéř vyhlásit osobní bankrot, čímž by byly všechny jeho dluhy smazány.

HYP. (už se po ni lehce nervózně divaá) V tom našem „finančním sektoru“ se stejně většina bankéřů chová stejně. Jeden od druhého si půjčují, ale nevrací nikdo nikomu. A když se někdo dožaduje plnění závazků příliš nahlas, zúčtují s ním ručně stručně. Kdepak, když jeden lehce přijde k penězům, měl by si na ně dávat pozor, jinak se mu může velmi lehce stát, že o ně stejně lehce zase přijde. Ted' by se mi hodilo koupit si nějakého pěkného chlapečka, abych z něho něco měl... No chybí mi hotovost, no!

POZN. Moment, tohle místo je ale interpretačně problematické. S tím chlapečkem to taky může být tak, že... (bankér na ni hodi zlý pohled) No dobře, tahle možnost je asi nejpravděpodobnější...

DAR. (vycházi s otrokem z Romantikova domu, otáč se a mluvi do domu) Když se pořádně najím, nemusíš mi už nic říkat. Všechno vím, všechno znám. Vyřídím ti tu záležitost s elegancí sobě vlastní, tak už mlč! ( $k$ sobě) Sakra, ale pěkně jsem se nacpal, jen co je pravda. Ale přece by se mi v břiše našel ještě jeden pokojíček, kam by se vešlo i to, co zbylo z toho, co zbylo... Ale počkat! Co to tam stojí za zahalenou osobu, co vypadá, že jde pozdravit Asklépia? No není to zrovna ten, koho hledám? (otrokovi) Pojd' honem, budu dělat, že ho neznám. (na Hypotéka, nasadi si pásku přes oko a šlape si na jazyk jako součást maskování) Hola hej, na flovíčko!

HYP. Nazdárek, Kyklope.

DAR. Profím?! Děláš fi ze mě blázna?

HYP. Já myslel, že tvoje máma byla kyklopka, ti mají přece jen jedno oko.

DAR. To byl, hochu, katapult. V bitvě u Fikyonu.

HYP. No, mně po tom dohromady nic není, ale netrefila tě spíš amfora s odpadky z kuchyně?

DAR. Ten dovede panečku věštit, že by strčil do kapsy i Sybillu Kumskou. Takovým řízeným střelám čelím docela často. ( $k$ Hypotékovi) Mladý muži, tohle zranění jfem utržil psi obraně vlafti. Je to znamení mé ftatečnofti, takže tohle mi profím nedělej. 
HYP. Tak ti mám udělat něco jinýho? (bližzi se $k$ němu s vilným úsměvem)

DAR. Nech fi ty fvoje fóra, teda fóry a radši mě doved' $k$ tomu, koho hledám, a bohatě fe ti odměním... fvou vděčnoftí. Hledám bankése Hypotéka.

HYP. Co mu chceš? A kdo tě posílá?

DAR. To ti hned seknu. Pofílá mě můj pán, voják Gaiuf Omnibuf Paco, sečený Poclufemcluf.

410 HYP. Hergot, toho moc dobře znám - jenom to pitomé jméno mi zabralo celé čtyři tabulky. A co tomu Hypotékovi chceš?

DAR. Doftal jfem psíkaz psinéft mu tenhle dopif.

HYP. A ty jsi kdo?

DAR. Já jfem jeho propuštěnec. Síkají mi Piuf.

HYP. Bud' zdráv... Pie. Ale řekni - proč se jmenuješ Pius?

DAR. To máš tak: já fe rád napiju, a když piju, tak fe pak chovám jako f tvrdým y...

HYP. Tak to si hledej společnost jinde - já se s žádným Piem kamarádit nebudu. Nicméně ten, koho hledáš, to jsem já.

420 DAR. Vážně? Ty jfi bankés Hypotékuf?

HYP. Osobně.

DAR. Mám ti od Gaia vysídit uctivé pozdravení a tohle ti pofílá.

HYP. Mně?

DAR. No tobě. Na, podívej fe na pečet. Poznáváš ji, ne?

HYP. Jak bych nepoznával? Voják se štítem půlí mečem ve dví slona...

DAR. Můj pán mi nasídil, abych ti vysídil, abyf bezodkladně zasídil, co je v tom liftu napfáno. Bude ti za to nefkonale vděčný.

HYP. Jen pomalu, nejdřív se pěkně podívám, co se tam píše.

DAR. Beze všeho, jak myflís. (stranou) Jen když to z tebe vymámím.

430 HYP. „Voják Gaius Omnibus Paco, řečený Poclusemclus, posílá pozdrav Hypotékovi, svému velectěnému hostiteli v Epidauru, a nechává se poroučet.“

DAR. (stranou) Je můj, sežral to i s navijákem.

HYP. „Co nejuctivěji tě žádám, abys muži, který ti přinese tento dopis, předal dívku, kterou jsem tehdy v Epidauru koupil - za tvé přítomnosti jakožto prostředníka -, spolu s jejími šperky a veškerým př́slušenstvím. Však víš, jak jsme se dohodli: kuplíri dáš peníze a dívku tomuto muži." A kde je tvưj pán? Proč nepř̌išel sám?

DAR. To je totiž tak. Psedevčírem jfme fe já a můj pán vrátili z Indie a on fi ted' chce 440 doma v Megalopoli nechat poftavit obrovfkou fochu z ryzího zlata. Fedmimetrový pomník fvých velkých činů.

HYP. Jakých činů?

DAR. Jen poflouchej. Během dvaceti dní fi úplně fám podmanil Peršany, Paflagoňany, taky Kartágo, Araby, Galatfké, Kretény... totiž Krétany, Fýrii, Rhodof i Američany...

POZN. (nadechuje se, že to chce komentovat)

DAR. (rovnou ji utne) Já vím, že to tam není!

(pokračuje) Pak taky Nenažranii a Nenapítii... 
POZN. Tohle tam náhodou je úplně přesně!

DAR. ...Kentaurii, Flotilii, Amazónii a celé Pobseží Kocoviny - zkrátka odhadem afi tak polovinu všech národů fvěta.

HYP. Hotový Alexandr Makedonský.

DAR. (ironicky) Ty mi nevěsúšs?

450 HYP. No já jen, že i kdybys všechny tyhle pronárody zavřel do ohrady jako kuřata, trvalo by ti minimálně rok, než bys ji jenom obešel kolem dokola. Ted' už je mi jasný, že musîš být od Gaiuse, když plácáš takové nesmysly.

DAR. A mám jich v záfobě ještě víc, kdybyf chtěl. (ve dveř́ch chrámu se objeví kupliřr)

HYP. To zrovna! Nemám na tebe celý den. Pojd' se mnou. Vyřídíme tu záležitost, kvůli které jsi prrišel. A hele, tady ho zrovna máme. Pornotéku, ty starej kuplíŕi, bud' zdráv!

PORN. Těbůh... teda, těbozi!

HYP. Tak jakpak si stojí ta naše záležitost?

PORN. Většinou spíš polehává. No tak, co potřebuješ?

HYP. Tady máš peníze a tady tomuhle dej tu holku.

PORN. To mám jako porušit př́ísahu?

HYP. Bylo by to snad poprvé? Hlavně že dostaneš svoje prachy, ne?

460 PORN. Dobrá rada nad zlato. Tak pojd'te.

DAR. $\quad$ A pofpěš fi, kuplísi, nemám čafu nazbyt. (všichni odejdou do kuplírova domu)

\section{Dějství čtvrté}

\section{Z hlediště přicházi chorégos.}

CHO. Pěkného hochštaplera si ten Romantikus sehnal, jen co je pravda. Ani nevím, jestli je tenhle Darmojed víc ovčák nebo čtverák. Docela se bojím, abych z něj vůbec dostal ten kostým, co jsem mu na dnešek půjčil. Ačkoli vlastně, s ním se nemusím vůbec dohadovat - beztak má všechny kostýmy na sebe napsané Romantikus. V každém případě se budu mít před tou hereckou pakáží na pozoru... Nicméně, určitě jim to ted' bude chvíli trvat, než zase přijdou na scénu, takže vám, milí diváci, konečně můžu povědět to, co jsem chtěl... A co jsem to chtěl?

POZN. Ehm, pardon, abyste věděli, co se tu děje, na tomto místě u Plauta přichází na jeviště chorégos - něco jako produkční - a vypráví publiku o tom, kde najdou v Římě různé typy lidí. Je to pro Plauta typický prvek zcizení, tedy vytržení z divadelní reality. Ve snaze dosáhnout podobného účinku jsme se chorégovo vystoupení rozhodli trochu aktualizovat...

CHOR. Nojasně, už vím. Já vám ted’ povím, kde tady v Brně co najdete, kdybyste to náhodou potřebovali a třeba vám zrovna nešel internet. Takže, nejlepší je vždycky začít na České - ať už potřebujete lepší mobilní tarif, chcete přispět na handicapované děti nebo si koupit nejnovější titul z knižní produkce Háre Kršna. A když budete 
mít štěstí, oblaží vaši duši rovnou nějaké to slovo Boží z úst zaručeného Mesiáše. Když zatoužíte po troše kultury, pokračujte na Svobodák a cestou určitě potkáte nejednoho skvělého muzikanta. Ti občas vyhrávají taky v myšině pod Hlavákem, ale tam není radno se z jistých důvodů zdržovat př́liš dlouho, i když tak nebezpečno jako v nočních hodinách na Cejlu tam zas není, nebojte. Zachce-li se někomu nějakého toho doupěte konzumu, nejblíž to bude mít asi do Špalíčku nebo do Vaňkovky, ale ten pravý konzumní požitek samozřejmě může nabídnout jedině Olympia. A pozor - jede tam od Vaňkovky zadara bus! Když budete chtít jen tak zevlovat, tak místní plankton se většinou schází v Denisových sadech, kousek od Šilingráku. Tam taky nedaleko najdete hned několik klubů, kde se po nocích schází budoucí elita národa. Ovšem pozor, poblíž je taky jeden, kde by se měli mít na pozoru obzvláště pánové a neohýbat se pro drobák upadlý na zem. A nebo právě naopak, to už záleží na vašich preferencích. Pro většinu pánů bude ovšem lepší volbou Moulin Rouge - ale ten už je tuším zavřenej. Teda ne že bych tam chodil... to jsem jen někde slyšel. Co se restauračních zařízení týče, ty najdete v Brně v podstatě na každém rohu, i když jejich kvalita a úroveň se samozřejmě různí. Pivo si tu můžete vypít jak v nóbl podniku, tak taky v nějakém pajzlu typu Pomaláč. Zkrátka vybere si každý... No nic, už slyším zase skř́ípat dveře, takže pokračování někdy příště. (odcházi zpět do hlediště)

POZN. Tak jak už jsem ř́kala, takhle to tam samozřejmě Plautus nenapsal, a abyste nebyli ochuzeni o původní znění a zároveň ho mohli porovnat s naší adaptací, dovolila jsem si vám ho tady nakopírovat. Pošlete si to dozadu... ${ }^{5}$

Z kuplírova domu vycházi Darmojed (stále v prestrojení), který vede Errotium, a za ním Pornotékus s Hypotékem.

DAR. Jen běž hezky psede mnou, holčičko, at tě mám pěkně na očích - teda na oku. (ke kuplírovi) Nezapomeň, jak pfal Gaiuf, že i všechny šperky a šaty jfou foučáftí obchodu.

PORN. To nikdo nepopírá.

DAR. No, ono je vždycky lepšejší fi to ujafnit.

490 HYP. Nezapomeň, kuplíri, jak jsme se dohodli. Kdyby se někomu čirou náhodou podařilo prokázat, že ta holka není otrokyně, dostanu svoje peníze nazpátek - třicet min!

PORN. Nezapomenu, bud' v klidu. Tvrdím snad něco jiného?

DAR. Ted' ne... Však já ti to včas psipomenu.

PORN. Vždyt jo. Tak a tady ti tedy oficiálně předávám své zboží.

DAR. Ty psedáváš mně něco fvého? To jfte celí vy kuplísi. Nemáte nic kromě té fvé huby nevymáchané, co zapse i nof mezi očima. Prodáváte, co není vaše, propouštíte, co vám nepatsí, a rozhodujete fi jen tak mir nichtf dir nichtf o cizích životech, jako by byly vaše vlaftní. Nikdo neudělá takovou hloupoft, aby fe za váf zaručil, a vy fami taky nikomu ručit nemůžete, i kdybfte chtěli. Podle mého jfte vy, kuplísi, zvláštní lidfký druh, něco jako mouchy, komási, štěnice, vši a blechy dohromady, proftě jako paraziti - na obtíž a jen pro zloft. Zkrátka abfolutně k ničemu. Žádný flušný

5 Původní Plautovo znění viz na konci scénáře. Možno též podobně přizpůsobit dle aktuálního místa inscenace. 
člověk fi vedle váf na fóru ani neftoupne. Bojí fe, že by fe na něj hned oftatní začali koukat fkrz prfty a šísit o něm pomluvy, jak mrhá penězi a nedbá na fvou dobrou pověft - ačkoli tseba vůbec nic špatného neudělal.

HYP. Koukám, že máš kuplíře přečtené jak slabikář, Kyklope.

DAR. Nemyfli fi, na bankése mám taky fvưj názor. Vy totiž nejfte o nic lepší. Kuplísi ještě afpoň dělají fvoji špinavou práci někde ftranou, ale vy fi klidně vyložíte krám psímo uproftsed fóra! Lákáte lidi na výhodný úrok a pak je fedsete z kůže, podobně jako oni (ukazuje na kuplíre) zaf v těch fvých doupatech hrají na lidfké pudy. Posád aby kvưli vám někdo novelizoval paragrafy o lichvě. A jen co fe fchválí, hned fi v nich najdete nějakou fkulinku a začnete je porušovat. Vy bankési fi ze zákonů děláte afi tolik jako čajové líftky z vlažné vody.

POZN. (hrozivě se vztyčí)

DAR. ( $\quad$ p poznámce) Já vím, já vím, Římani neměli čaj. (znovu k Hypotékovi) Vy bankési fi ze zákonů něco děláte tak možná ve fvětě, kde je vasící voda ftudená...

POZN. No budiž.

HYP. Že jsem radši nemlčel.

PORN. Teda, jde ti to fakt dobře, mluvit o někom takhle nedobře...

DAR. Kdybych mluvil nedobse o dobrých lidech, uznávám, že by to fkutečně nebylo dobré. Ale mluvit nedobse o lidech nedobrých je podle mého fkromného úfudku docela v posádku. Zkrátka, Pornotéku, od tebe já bych fi nic nekoupil. Ani od žádného jiného kuplíse. Tečka. Hypotéku, chceš něco?

HYP. Jen ti dát sbohem.

DAR. Fbohem! (otáč́ se $k$ odchodu)

PORN. Hej ty! Ještě jsme neskončili.

DAR. A co ještě chceš?

PORN. Dávej mi na ni pozor, aby se jí nic nestalo. Je to slušné děvče, víšs, co tím myslím. Vychovával jsem ji jako vlastní.

DAR. Když ti na ní tak záleží, dáš mi něco navíc, abych fe mohl lépe poftarat o její pohodlí?

PORN. Leda pár facek!

DAR. Fám byf zafloužil...

520 PORN. Co fňukáš, ty hloupá? Neboj se, prodal jsem tě sakra dobře, tak bud' hodná holka a běž pěkně s ním, krasavice moje.

HYP. Chceš ode mě ještě něco, Pie?

DAR. Bud' f bohy a měj fe. Díky psevelice za tvé peníze a tvoji roli v tomhle dramatu.

HYP. Vyřid' šéfovi uctivé pozdravení.

DAR. Vysídím. (odcházi s Errotium jakoby směrem do města, pak ale nenápadně, zatímco se kupliř s bankérem bavi, zajdou do Romantikova domu)

HYP. A ty mi ještě něco chceš, kuplî́ri?

PORN. Jo, těch deset min, at mám vůbec z čeho žít, než se trochu zmátořím.

HYP. Dostaneš je, zítra si pro ně pošli. (odcházi směrem do města) 
PORN. To se mi ten obchod hezky povedl - ted' půjdu sem do svatyně obětovat bohům šafrán a trochu toho zázvoru. To děvče jsem totiž kdysi dávno koupil jako malou žábu za deset min. Ted' mě tak napadá, že toho člověka, co mi ji prodal, jsem už 530 pak nikdy neviděl. Ten už bude nejspíš dávno pod drnem. Ale co je mi po tom? Hlavně že mám svoje prachy. Komu holt bozi přejí, tomu štědře nadělují. Ted' se půjdu postarat o tu obět. Musím přece myslet na svoji budoucnost. (odcházi do chrámu)

Za hudebniho doprovodu pricházi voják se suým průvodem směrem od města. Vede s sebou bankére.

GAI. (zpěv) Svou chot!! Svou choț! Já přišel pro svou chot!!

Ji sevřít v náruč svou jak ve svěrák!

Sem s ní, mám spěch, mění se světa běh!

Nutno břicha párat, města bořit, z živých vyrazit dech!

OTR. I. Hele, ta hrud"!

OTR. II. Hele, ten meč!

OTROCI Hele ho!

GAl. Já, miles gloriosus, já, zvěrstev laureatus, já jediná báseň jsem a chytrý jak lišák, všech žen já kabrňák i nahý fešák jsem.

Já jsem ideál!

OTR. I. Slyšte ten hlas!

OTR. II. ̌inčí jak zbroj!

OTR. I. Hele, ten pás plný žláz!

OTR. II. Jaký to mocný stroj!

GAI. Mou chot!! Mou chot!! Informujte mou chot, že má náruč už čeká na objetí.

Mám spěch! Mám spěch! Utíká dějin běh.

Je čas hrobky ted' rabovat a města vyplundrovat, brát a krást - kořistí plnit lod"!

Přived'te mi mou chot! $!^{6}$

GAI. ( $k$ publiku) Přicházím naplněn hněvem, a to ne jen tak ledasjakým, ale takovým, s jakým mám ve zvyku rovnat města se zemí!

POZN. Tak to je chlubivý voják, miles gloriosus. Myslím, že není potřeba víc dodávat...

GAI. (prudce se otoči na bankére) Jestli mi okamžitě bez mžiknutí oka nevrátíš těch třicet min, které jsem si u tebe uschoval, vmžiku se rozluč se životem.

HYP. Spíš budeš brzy naplněn lítostí, a ne jen tak ledasjakou, ale takovou, jaká přepadá všechny, kterým nic nedlužím.

6 Text a melodie písně převzaty z muzikálu A Funny Thing Happened on the Way to the Forum v překladu Jana Wericha. 
GAI. Ty... Nechtěj mě rozzuřit. Snad si nemyslís, že tě budu prosit na kolenou.

540 HYP. A ty mě zase nikdy nedonutíš vracet něco, co jsem ti už vrátil. Nic ti nedám!

GAI. Přesně tak jsem si myslel, že to dopadne, když jsem ti ty peníze svěřoval - že už je nikdy neuvidím!

HYP. Pak už vůbec nechápu, proč je ted' ode mě chceš zpět.

GAI. Chci vědět, komu jsi je dal!

HYP. Tomu tvému Pyj... Piovi jsem je vrátil - aspoň říkal, že se tak jmenuje - tvému propuštěnci. Měl s sebou tenhle dopis, zapečetěný tvým-

GAI. (přeruši ho) O jakých pitomých propuštěncích a Piích mi to tu fantazíruješ? Žádného propuštěnce nemám.

HYP. A dobře děláš. Ne jako ti kuplírí, co mají propuštěnců davy, ale klidně je nechávají ve štychu.

GAl. Takže co teda?

HYP. Co by? Já jsem jen splnil tvůj rozkaz, protože mám k tobě respekt. Přece jsem nemohl odmítnout posla, který přišel s tvojí pečetí.

GAI. Jsi tupější než tupost sama, že jsi mu uvěřil!

HYP. Přinesl řádně zapečetěný dopis, zrovna takový, jaký si mezi sebou posílají úředníci, tak co bych mu nevěřil? Zkrátka tvoje peníze byly v pořádku vyplaceny, takže to bychom měli a já půjdu. Měj se dobře, udatný válečníku. (odcházi směrem do města)

GAI. Jak se mám ted' mít dobře?

HYP. Tak se měj třeba špatně, když chceš. Pro mě za mě...

GAI. (k publiku) Co mám ted' dělat? Co mi ted' pomůže, že jsem srazil do prachu země mocné krále, když si ze mě dnes vystřelil tenhle budižkničema? (odcházi směrem do města)

Z chrámu vycházi Pornotékus.

PORN. (vycházi z chrámu) Mám dojem, že bohové se těžko můžou hněvat na někoho, komu jsou evidentně př́ínivě nakloněni. Jak jsem tady v chrámu vykonal oběti, hned mě napadlo, že bych si měl od bankéře ty peníze vyzvednout radši hned, aby mi s nimi nepláchl až někam k Pontu. Přece ho nenechám, aby si s nimi užíval, když si za ně můžu hezky užít sám.

GAI. (vraci se od města) Pózor! Pohov! Nazdar!

PORN. Zdar, Gaiusi Omnibusi Paco!

POZN. Proboha! Gaie Omnibe Pacone! O tempora, o mores...

PORN. Zdar, Gaie Omnibe Pacone! No, předtím to teda znělo líp.

Vidím, že jsi štastně dorazil $\mathrm{k}$ nám do Epidauru. Tak to u mě dnes večer... nedostaneš ani slanou vodu.

GAI. Díky za tvou pohostinnost, Pornotéku, rád přijdu a... dám ti co proto! Jakpak se u tebe daří mému zboží? 
PORN. Noo, u mě nijak. Už ti přece nic nedlužím. A mám na to svědky.

GAI. Cože?

PORN. Udělal jsem, co jsem slíbil.

GAl. Okamžitě mi přived' tu holku, nebo tě nabodnu na svůj meč jako na rožeň, ty lotře vypráskaná!

PORN. Sám se běž bodnout, ty nafrněná nádhero! Co mi tady vyhrožuješ? Holku si odsud 570 odvedli, ale tebe budou muset odnést, jestli mě budeš dál takhle urážet. Zvlášt když ti nedlužím vủbec nic, leda tak pár facek...

GAl. Tak ty mi chceš dát pár facek?

PORN. A nezůstane u toho, že chci - rovnou ti je dám, jestli budeš ještě chvíli prudit.

GAl. Nějaký kuplír si tady na mě nebude otvírat hubu a všechny mé vítězné bitvy a válečnou slávu zadupávat do prachu. Tenhle meč a štít už pomohly rozprášit nejeden šik. Nevydášli mi tu dívku, postarám se o tebe tak, že tě z bojiště budou muset odnést mravenci - po kousíčkách!

PORN. Tenhle hřeben, tohle zrcátko, (postupně vytahuje ze záhybu tógy) tyhle natáčky, tahle pudřenka, tenhle ručníček a tyhle kleštičky na obočí už pomohly okrášlit nejeden ksicht. Z těch tvých nabubřelých řečí a výhružek si dělám asi tolik jako z uklízečky, co u mě myje latrínu! Vydal jsem tu dívku tomu, kdo mi od tebe donesl peníze.

GAl. A to byl kdo?

PORN. Nějaký Pi... ius. Říkal, že je tvůj propuštěnec.

GAI. Můj propuštěnec? No to snad né! To musel být určitě Darmojed, už je mi to jasné. Že já hlupák mu sedl na lep! To on mě připravil o můj pečetní prsten, o moji chloubu...

PORN. (lasciuně) Jestli tě, Gaiusi, Darmojed připravil o tvoji chloubu, tak u kopiníků už si asi nevrzneš, co?

GAl. Kde najdu Darmojeda?

PORN. Nejspíš tam, kde může něco spadnout od stolu. A vsadím se, že jich tam najdeš i víc. No nic, já jdu, sbohem a šáteček, vojáku. (odcházi do svého domu)

GAI. Sbohem a oprátku, ty lotře! Co mám ted' dělat? Mám tu počkat, nebo ho jít hledat? Je vůbec možné, že jsem se nechal takhle opít rohlíkem? Vyplatím štědrou odměnu tomu, kdo mě zavede k tomu mizerovi Darmojedovi! (odcházi směrem do města)

\section{Dějství páté}

Darmojed vybihá z Romantikova domu.

DAR. ( $\quad$ p publiku) Slyšel jsem, že nějaký tragéd...

POZN. Ř́ká se tragik, ty seš tragéd! ( $k$ publiku) Bože, to je materiál...

DAR. Slyšel jsem, že nějaký tragik prý kdysi napsal, že dvě ženské jsou vždycky horší než jedna. Svatá pravda, říkám vám. Ale jaktěživ jsem neviděl strašnější ženskou, než je tahle Romantikova holka. Ani jsem nikdy o žádné takové neslyšel. Vlastně to ani 
nejde - takovou by nikdo ani nemohl vymyslet! Jen co uviděla ten prsten, hned se ptala, odkud ho mám. „Proč se ptáš?“ já na to a ona, že prý to potřebuje nutně vědět. A já jí říkám, že jí to neřeknu. A ona? Aby mi ho vyrvala, zakousla se mi do ruky! Tak tak jsem se té divé sani vytrhl a utekl před ní ven!

ERR. (vybihá z Romantikova domu, volá na Romantika, který ji následuje) Pospěš, miláčku!

ROM. Proč? Co se děje?

600 ERR. $\quad$ Chyt ho, at ti neuteče! (ukazuje na Darmojeda) Ted' jde o všechno!

DAR. Zato já nemám nic. Všechno, co jsem měl, je to tam.

ROM. (chyti Darmojeda) Mám ho. O co vlastně jde?

ERR. Zeptej se ho, odkud má ten prsten. Takový nosíval můj otec.

DAR. (výsměšně) A taky moje teta z matčiny strany.

ERR. Dala mu ho maminka.

DAR. A tobě zas tvůj tatínek.

ERR. Mluvís z cesty.

DAR. Jo, to mi jde. Díky tomu je ta cesta životem hned snazší. Takže co teda?

ERR. Bud' tak hodný a nebraň mi najít moje rodiče.

DAR. Já že ti v tom bráním? Podle tebe jsou snad zakletí tady v tom prstenu?

ERR. Narodila jsem se jako svobodná!

DAR. To i spousta dalších, co jsou dneska otroci.

ROM. Tak ted' už toho ale začínám mít dost!

DAR. Už jsem ti přece ř́kal, jak jsem k tomu prstenu přišel. Kolikrát to mám opakovat? Obehrál jsem o něj Poclusemcluse. V kostkách.

610 GAl. (právě přicházi i s doprovodem z města) To mám ale štěstí, tady ho máme. Jak to jde, dobrý muži?

DAR. Ted' to začalo trochu pokulhávat. (snaži se odvést pozornost) Takže, na tři hody, jsi pro? O tvůj plášt.

GAI. Strč si ty svý hody, hody, doprovody někam a koukej mi vrátit ty peníze nebo tu holku!

DAR. Jaký peníze? Co to tady vykládáš za nesmysly? Jakou holku ti mám vrátit?

GAI. Tu, co jsi dneska odvedl od kuplíre, ty lotře zrádná.

DAR. Žádnou holku jsem odnikud neodvedl.

GAI. Ale odvedl, vždyẻ ji tu vidím.

ROM. Tato dívka je svobodná!

GAI. Moje otrokyně, které jsem nikdy nedal svobodu, ta že je svobodná?

ROM. Tak mi řekni, kdo ji svěřil do tvé moci nebo kdo ti ji prodal.

GAI. Zaplatil za ni můj bankéř. Však mi ty a kuplír ty peníze vrátíte. A k tomu čtyřnásobek (do publika) znalci římského práva vědí - čtyřnásobek původní částky jako penále!

620 ROM. Když si myslíss, že si můžeš kupovat svobodné občanky, navíc kradené, tak si mě dej třeba $\mathrm{k}$ soudu. 
GAI. To zrovna!

ROM. Ztratils koule, co?

GAI. (podívá se doli̊) Neztratil...

ROM. No, jak tě tak pozoruju, ty žádný tvrdý... argumenty nemáš. Takže tě dám k soudu já. ( $k$ Darmojedovi) A ty mi budeš svědčit.

GAI. Otrok a svědčit u soudu?

DAR. Tu máš, aby sis pamatoval, že já nejsem žádný otrok! (bije ho) A ted’ můžeš jít třeba k soudu, saláte.

GAl. $\quad$ A tady máš ty! (vrací úder)

DAR. Pomoc, římští občané!

GAI. Co křičíšs?

ROM. Co na něho saháš?

GAl. Protože se mi chce.

ROM. (k Darmojedovi) Pojd' sem, já to s ním vyřídím. A neřvi!

ERR. Romantiku, probohy tě prosím, zachraň mě!

ROM. Neboj se, postarám se o tebe jako o sebe sama - nebo jako o svého anděla strážného. Gaie, řekni mi, prosím tě, odkud máš ten prsten, o který tě Darmojed připravil.

ERR. Objímajíc tvá kolena, snažně tě prosím, pověz nám to!

POZN. Ehm, tady bych jen chtěla upozornit na krásné tragické gesto, při kterém prosebník, v tomto př́ípadě prosebnice jednou rukou objímá kolena tomu, koho prosí, a druhou rukou mu sáhne... (Errotium se natahuje $k$ rozkroku, Poznámka se zděsi a nasměruje ji správně) Né, na bradu! Tak.

GAI. Co je vám po tom? To byste se rovnou mohli zeptat, odkud mám třeba tenhle plášt nebo tenhle meč.

DAR. No jo, už se zase naparuje, miles jeden gloriosus.

GAI. Pošli ho někam... pryč a já vám všechno řeknu.

DAR. To jeho všechno bude stejně stát za starou belu.

ERR. Prosím tě, řekni mi to.

GAl. Ǩeknu. Vstyk! Ted' mě všichni dobře poslouchejte. Ten prsten patřil mému otci Fatalerroriovi. Na smrtelné posteli ho dal mně - jak se to sluší - jakožto svému synovi.

ERR. Při bozích!

GAI. A tak mě ustanovil svým dědicem.

640 ERR. Bohové rodinného krbu, stůjte při mně, vždyt já jsem vás vždy měla v úctě. Bud' zdráv, bratře můj!

GAI. Co? Ty? Sestra? Moje? Jestli je to pravda, tak mi teda řekni, jak se jmenovala naše matka?

ERR. Klytaimnestra.

GAl. A chůva? 
ERR. Nutricie. To ona mě tenkrát o Dionýsiích vzala s sebou do divadla. Sotva jsme tam přišly a usadila mě na sedadlo, přihnal se uragán a tribuny se zř́itily k zemi. Hrozně jsem se bála. A najednou mě kdosi popadl - celá jsem se tř́sla, byla jsem polomrtvá strachy - ani nevím, jak mě odtamtud odnesl.

GAl. Vzpomínám si na tu hrůzu. Ale řekni mi, kde je ted’ ten člověk, co tě tehdy unesl?

ERR. Nemám tušení. Ale dodnes mám u sebe prsten, který jsem měla, když jsem se tehdy ztratila.

GAI. Prsten?! Ukaž, at se podívám.

DAR. Blázníš, nedávej mu ho!

ERR. Nech toho. (podá prsten vojákovi)

GAI. U všech bohů olympských, vždyt je to ten prsten, co jsem ti dal k narozeninám! Za to dám ruku do ohně. Sestro!

ERR. Bratře!

ROM. Bohové at̉ požehnají tomuto štastnému setkání.

660 DAR. A taky nám všem. Omnibusi, měl bys, myslím, dnes uspořádat hostinu díkůvzdání za sestry-nalezení a Romantikus zas zítra hostinu svatební. Rádi přijdeme.

ROM. Bud' už zticha!

DAR. Nebudu, když to tak dobře dopadlo. Vojáku, dej svou sestru za ženu tady Romantikovi. Já jí dám věno.

GAI. Ty a věno?

DAR. No ovšem - dokud bude živa, bude mít tu výsadu mě živit. To myslím naprosto vážně.

GAI. Tak to je od tebe opravdu laskavé. No, a kuplíŕ nám ted' dluží třicet min.

ROM. Kuplír nám? Za co?

GAl. Zapř́isahal se mi totiž, že kdyby někdo prokázal, že je Errotium svobodného původu, bez řečí mi vrátí všechny peníze. Takže se jde za kuplî́rem. Pochodem v chod!

DAR. Skvělý nápad!

ROM. Počkat, nejdřív musíme vyřídit tu moji záležitost.

GAl. Jakou tvoji záležitost?

ROM. Slib mi, že mi ji dáš za ženu.

DAR. Tak na co čekáš, Paco? Dej mu ji za ženu.

GAI. Jestli si to má sestra př̀je...

ERR. Z celého srdce si to přeji, bratře!

GAI. Tak dobře.

DAR. Dobře děláš.

ROM. Gaie Omnibusi Paco (Poznámka si významně odkašle), slibuješ mi tímto ruku své sestry?

GAI. Slibuji.

DAR. A já ti ji taky slibuji. 
GAl. To je od tebe moc hezké... A hele, koho to nevidím? Kuplî́r. A jde přímo k nám, i s mými penězi.

PORN. (vycházi ze svého domu, mluvi do publika) Kdekdo říká, že svěřit peníze bankéři je 680 špatná investice - taková hloupost. Já říkám, že to může být investice dobrá, nebo špatná. Sám jsem si to dnes ověřil na vlastní kůži. Ačkoliv - svěřit peníze bankéři (který je stejně nevrátí), to ani není špatná investice - to je můžeš rovnou hodit do kloaky. Tak např́klad Hypotékus - aby mi mohl vyplatit těch deset min, obešel všechny bankéře, ale nebylo z toho nic, tak jsem se začal domáhat svých peněz pěkně nahlas. A on, že půjdeme k soudu. Měl jsem pěkně nahnáno, aby náhodou před prétorem nevyhlásil bankrot - z toho bych pak moc neměl. Ale kamarádi ho zmáčkli, takže mi nakonec zaplatil pěkně ze svého. Ted’ můžu konečně běžet domů.

GAI. Hej, kuplíri, chci s tebou mluvit.

DAR. Já s tebou chci taky mluvit.

PORN. Zato já s vámi mluvit nechci ani s jedním.

GAl. Stůj, povídám! Zastavit, stát!

DAR. A koukej hned a okamžitě vysolit ty prachy!

PORN. My snad spolu něco máme? Nebo my dva? (chystá se odejít)

690 GAl. Třeba to, že z tebe asi brzy udělám nezřízenou střelu a nechám tě natáhnout... na katapult. A vystřelit!

DAR. A já se zase postarám, aby ses v base pěkně ohnul... až ti dají na krk železný obojek jako psovi.

PORN. To spíš já nechám zavř́ít vás dva. Do nějaké pořádné kobky, až zčernáte.

GAI. ( $\quad$ jednomu ze svých otroků) Vezmi ho pod krkem a na šibenici s ním.

DAR. Tam skončí tak jako tak.

PORN. Ach, bohové olympští, občané římští, kam mě to táhnou? Bez soudu? Beze svědků? Errotium! Romantiku! Při bozích vás prosím, pomozte mi!

ERR. Bratře, snažně tě prosím, nezabíjej ho... bez soudu. Staral se o mě vždycky dobře a ani jedinkrát se mě nedotkl.

GAl. To ale není jeho zásluha! Za to, že jsi ještě panna, můžeš děkovat jedině Asklépiovi, 700 protože kdyby tenhle darebák byl býval zdravý, už dávno by tě nabízel každému, kdo by jen trochu chtěl.

ROM. Poslouchejte, já bych tu vaši záležitost mohl urovnat. Ty ho pust' a ty pojd' sem, kuplírii. Já vás rozsoudím, pokud ovšem budete ochotní podřídit se mému rozsudku.

GAI. Tak nás rozsud'.

PORN. Jen pod podmínkou, že mě tvůj rozsudek nepřipraví o peníze.

GAI. Ty peníze, cos slíbil vrátit?

PORN. A jak jako?

ROM. Dal jsi mu svoje slovo.

PORN. Jo? (k vojákovi) A kde ho máš? A vůbec, slova používám, když chci někomu něco sdělit, a ne se zruinovat. 
ROM. (k otrokovi) Tohle nemá cenu, tak ho zase chytni pod krkem...

PORN. Nééé, slibuju, že udělám všechno, co mi řekneš.

GAI. No vidís, jak se umíš pěkně chovat. A ted' mi odpověz na jednu otázku.

PORN. Ptej se, na co chceš.

710 GAl. Slíbil jsi, že pokud někdo prokáže, že je tahle dívka svobodná občanka, vrátís mi všechny peníze? Ano, nebo ne?

PORN. To že jsem říkal? To si opravdu nepamatuji.

GAI. Takže to popíráš?

PORN. Jo, to teda sakra popírám! Kde jsem to měl říct? A máš na to svědky?

DAR. Já jsem svědek. A bankéř Hypotékus.

PORN. Budeš zticha?

DAR. Nebudu! Z tebe si houby dělám, ty mi strach nenaženeš. Slíbil jsi to, já sám jsem u toho byl a taky Hypotékus.

ROM. Věřím tvému svědectví. Kuplíři, poslechni si tedy můj rozsudek: Ona je svobodná, (postupně ukazuje) on je její bratr, tudíž ona je jeho sestra, já si ji beru za ženu a ty vrátís Gaiovi peníze. Jednání skončeno.

GAI. A jestli mi ty peníze nevrátî́s hned, tak tě dám zavřít, až zčernáš.

PORN. Tys to tedy náramně nestranně urovnal, Romantiku. Ale ono se ti to vrátí, jen 720 počkej. A tebe, Gaie, zatraṫtež všichni bohové a všechny bohyně! A ted' pojd' se mnou.

GAI. S tebou? A kam?

PORN. K prétorovi, to ted' bude můj osobní bankéř. Tak zaplatím všem, komu jsem co dlužen.

POZN. Viz můj komentář k verši 376. (chvili hledi na nechápajici publikum) No prostě, že u prétora mohl Říman vyhlásit osobní bankrot, čímž se zbavil všech dluhů...

GAI. Rovnou do basy tě odvleču a k žádnému prétorovi, jestli mi ty peníze nedáš!

PORN. Nejradši bych, kdybys zhebnul, abys věděl.

GAl. Vážně?

PORN. No sakra vážně!

GAI. No, jak tak znám svoje pěsti...

PORN. Tak co?

GAI. „Tak co“ se ptáš? Jestli mě budeš provokovat, pěkně tě s nima zpacifikuju.

PORN. No dobře, dostaneš ty peníze.

GAl. Ale hned ted!

PORN. Samozřejmě.

ROM. Gaie, zvu tě k sobě na hostinu. Vystrojíme svatbu ještě dnes.

DAR. At̉ to všechno štastně dopadne a dobře se daří mně i vám. Diváci, zatleskejte nám! 


\section{Původní znění chorégova vstupu}

CHO. Pěkného hochštaplera si ten Romantikus sehnal, jen co je pravda. Ani nevím, jestli je tenhle Darmojed víc ovčák nebo čtverák. Docela se bojím, abych z něj vůbec dostal ten kostým, co jsem mu na dnešek půjčil. Ačkoli vlastně, s ním se nemusím vůbec dohadovat - beztak má všechny kostýmy na sebe napsané Romantikus. V každém případě se budu mít před tou hereckou pakáží na pozoru... Nicméně, než zase přijdou na scénu, povím vám, kde tady v Ř́mě koho najdete, abyste to věděli, když ho budete hledat - at' už ty nečestné, nebo ty počestné, poctivce nebo neřády, a tak dál. Kdo by chtěl vidět prolhance, tak ti sedí támhle v senátu. Kdo hledá kecálky a chvastouny, najde je u Kanálu - tam co je chrám Venuše Kloacké. Zazobané a rozhazovačné manžílky najdete s největší pravděpodobností támhle u baziliky, stejně tak vysloužilé šlapky a lichváře, co vám klidně dají půjčku per hubam. Holubí letka hřaduje na rybném trhu, zatímco ve spodní části fóra nerušeně korzuje místní honorace. To uprostřed, kolem Kanálu, se promenádují čistě jen frajírci. Tady nad Curtiovým jezírkem se to zase hemží arogantními velkohubými mizery, kteří drze pro nic za nic urážejí ostatní, a přitom by si měli sami zamést před vlastním prahem. Kolem Starých krámů se motají nóbl bankéři. Stejně tak támhle za Kastorovým chrámem máme skupinku, které bych, být vámi, radši moc nevěřil. Na Velabru svoje zboží prodávají pekaři, řezníci a věštci. V Etruské čtvrti, tam zase najdete ty, co nemají na prodej nic - jen sami sebe - co se zkrátka snadno ohnou anebo nechávají ohýbat jiné. Zazobané a rozhazovačné manžílky hledejte jedině u proslulé madam Lefkady. No prostě v oppijském bordelu. Ale už slyším skřípat dveře. Radši bych měl držet jazyk za zuby. 